\title{
KRIMINALISASI MATCH FIXING DALAM PERTANDINGAN SEPAKBOLA DI INDONESIA BERDASARKAN UNDANG-UNDANG NOMOR 11 TAHUN 1980 TENTANG TINDAK PIDANA SUAP
}

\author{
Alexzander Rinaldy \\ (Mahasiswa Progarm S1 Fakultas Hukum Universitas Tarumanagara) \\ (E-mail: alexzanderrinaldy@gmail.com) \\ Dian Adriawan Daeng Tawang \\ (Corresponding Author)
}

(Dosen Hukum Pidana, Universitas Tarumanagara dan Universitas Trisakti, Meraih Sarjana Hukum dari Universitas Hasanuddin, Magister Hukum dari Universitas Hasanuddin, dan Doktor Ilmu Hukum dari Universitas Hasanuddin)

(E-mail: Dianadriawan@yahoo.com)

\begin{abstract}
The current football competition has changed because it began to be infiltrated by organized criminals, especially in match manipulation and match fixing. Setting scores and match manipulation as a global threat in the world of football. The problem faced in writing this essay is how to criminalize match fixing in soccer matches in Indonesia based on Law Number 11 of 1980 on the Crime of Bribery. The research method used in this research is normative legal research that is research which gives systematic explanation of rules governing a certain legal category, analyze the relation between regulation explain difficulty area and may predict future development. The results showed that the criminalization of match fixing in Indonesian soccer matches based on Law Number 11 of 1980 on the Crime of Bribery was threatened with a criminal sanction although bribes in the private sector can't be regarded as an act of corruption because they do not belong to the category of corruption based on Corruption Act. This means that it does not mean it has no impact at all in enforcing the rule. In fact, the non-regulation of bribery in the private sector in Corruption Law is related to the actors who can eradicate and enforce the provisions. Bribes (as well as corruption in general) in the private sector have brought so many bad impacts on the business sector including in football matches.
\end{abstract}

Keywords: Criminalization, Match Fixing, football. 


\section{Pendahuluan}

\section{A. Latar Belakang}

Sepakbola menjadi salah satu olahraga favorit nomor wahid masyarakat global. Sejak jaman dulu hingga saat ini sejarah sepakbola dunia hampir tidak pernah mengalami fase kemunduran meskipun terkadang ada dinamika yang mengiringi perjalanannya, tak terkecuali masalah pengaturan skor (match fixing). ${ }^{1)}$ Pengaturan skor yang semakin tahun naik ke permukaan menjadi sebuah rumor yang patut untuk ditindaklanjuti secara serius oleh seluruh pemangku kepentingan (stakeholder) yang ada, karena suara yang semakin nyaring membicarakan hal tersebut.

Di sisi lain, kompetisi sepakbola saat ini telah berubah karena mulai disusupi oleh pelaku kriminal secara terorganisasi, terutama dalam manipulasi pertandingan dan pengaturan skor. Pengaturan skor dan manipulasi pertandingan sebagai ancaman global, ibarat seperi virus kanker yang terus menyebar dan tidak melihat ada tempat yang aman dari match fixing dan match manipulation di dunia ini. Semua wilayah di dunia ada ancaman yang sama. Setiap kegiatan sepakbola di bawah Federation of International Football Association (FIFA), selalu ada upaya infiltrasi dari kejahatan yang terogranisir ini. ${ }^{2)}$

Berdasarkan pandangan FIFA bahwa pengaturan skor yang terjadi dalam dunia si kulit bundar biasanya telah direncanakan secara kriminal dan berada pada tingkat transnasional yang termasuk dalam kejahatan judi, maupun korupsi secara personal atau bahkan kelembagaan. Biasanya hal semacam ini lebih sering menyerang klub yang bermain di liga suatu

1) Luthfy Avian Ananda, "Match Fixing dalam Sepakbola Indonesia Ditinjau dari Perspektif Hukum Pidana", https://www.kompasiana.com/luthfyavian/match-fixing-dalamsepakbola-indonesia-ditinjau-dari-perspektif-hukum-pidana_5693d48e119773750970f220, diakses tanggal 18 Januari 2018.

2) Ali, "FIFA: Sepakbola Telah Disusupi Kejahatan Terorganisir", http://www.hukumonline.com/berita/baca/lt5270ce5840661/fifa--sepakbola-telah-disusupikejahatan-terorganisir, diakses tanggal 16 Februari 2018, hal. 1. 
negara tertentu ketimbang event-event besar yang diselenggarakan oleh FIFA sendiri dan melibatkan tim nasional. ${ }^{3)}$

FIFA memiliki sistem peringatan dini untuk pola monitoring perjudian dan telah mendirikan kerjasama bilateral dengan interpol. Di mana negara-negara tertentu yang menjadi anggota Uni Eropa telah menyertakan penipuan olahraga dalam hukum pidana (seperti Italia dan Portugal), negara lainnya telah memasukkan ke dalam undang-undang olahraga (Yunani dan Polandia), sementara di negara anggota lainnya tidak dianggap sebagai tindak pidana. ${ }^{4)}$

Tentunya dalam hal ini, Uni Eropa tidak dapat melakukan ini dengan sendiri. Semua pemegang saham organisasi olahraga, operator perjudian, lembaga penegak hukum, institusi Eropa dan lembaga permasyarakatan berperan penting dalam pendekatan yang komprehensif. Ini adalah langkah satu-satunya pengaturan skor pertandingan di Eropa dapat ditangani secara efektif.

Terkait dengan match fixing di Indonesia, tentunya hal ini bukan barang baru dalam dunia olahraga kita, kehadirannya nyata dan dapat dirasakan namun pembuktiannya begitu sulit. Dalam hubungan ini, motif utama terkait pengaturan skor adalah uang. Sindikat judi bermodal besar berani membuat skenario terkait suatu hasil pertandingan karena mereka memiliki banyak uang untuk bermain dibanyak titik. Namun harus dipahami bahwa selama tak memenuhi unsur-unsur tertentu yang diatur secara pidana maka suatu pengaturan skor tak dapat dimasukkan kategori kejahatan/kriminal namun tetap saja mencederai fairplay, karena ada juga pengaturan skor yang motifnya bukan uang tetapi murni strategi untuk menghindari atau memilih lawan dan sebagainya.

Kejelasan motif menjadi sangat penting dalam pengusutan pengaturan skor, karena sepanjang tak memenuhi unsur delik pidana maka urusan

\footnotetext{
3) Luthfy Vian, Ibid., hal. 2.

4) Emine Bozkurt, "Match Fixing and Fraud in Sport: Putting the Pieces Together", http://www.europarl.europa.eu/document/activities/cont/201209/20120925ATT52303/20120925A TT52303EN.pdf, diakses tanggal 16 Februari 2018.
} 
sanksi hanya sebatas ada di tangan Komisi Disiplin (Komdis), Komisi Banding (Komding) dan Komisi Etik PSSI. Begitupun sebaliknya, ketika proses penyelidikan dan penyidikan menemukan fakta lain yang melibatkan banyak pihak-pihak seperti wasit, hakim garis, pelatih dan bahkan bandar judi, mafia dan lain-lain, maka federasi tak dapat menjangkaunya dan harus menggandeng aparat penegak hukum untuk memberantasnya.

Sistem pencatatan peraturan yang buruk dan banyaknya peraturan (hampir setiap undang-undang) yang memiliki ketentuan pidana di Indonesia (dan tidak terkodifikasi) membuat Undang-Undang Nomor 11 Tahun 1980 tentang Tindak Pidana Suap yang sangat relevan diterapkan justru menjadi "aturan yang terlupakan". Hal itu diperparah oleh minimnya publikasi tentang aturan ini. Jangankan orang awam, penegak hukum sekalipun banyak yang tidak mengetahui peraturan ini. Contoh dilepasnya Johan Ibo adalah bukti nyata, karena pihak kepolisian melihat konteks suap mengacu kepada Undang-Undang Nomor 20 Tahun 2001 tentang Perubahan Atas Undang-Undang Nomor 31 Tahun 1999 tentang Pemberantasan Tindak Pidana Korupsi (UU Tipikor) yang tentu saja tidak relevan dalam kasus ini.

Langkah maju Indonesia dengan menerbitkan Undang-Undang Nomor 11 Tahun 1980 tentang Tindak Pidana Suap sebenarnya bisa menjadi terobosan untuk menjerat semua tindak pidana suap di sektor swasta (non-government), namun karena kondisi politik rezim orde baru yang melindungi swasta kolega penguasa dan euforia reformasi yang menempatkan suap menjadi populer dalam konteks UU Tipikor, maka undang-undang yang sebenarnya masih eksis dan berlaku ini menjadi terlupakan.

Sistem pencatatan peraturan yang buruk dan banyaknya peraturan (hampir setiap undang-undang) yang memiliki ketentuan pidana di Indonesia (dan tidak terkodifikasi) membuat Undang-Undang Nomor 11 Tahun 1980 tentang Tindak Pidana Suap yang sangat relevan diterapkan justru menjadi "aturan yang terlupakan. Hal itu diperparah oleh minimnya 
publikasi tentang aturan ini. Jangankan orang awam, penegak hukum sekalipun banyak yang tidak mengetahui peraturan ini. Contoh dilepasnya Johan Ibo adalah bukti nyata, karena pihak kepolisian melihat konteks suap mengacu kepada Undang-Undang Tindak Pidana Korupsi (UU Tipikor) yang tentu saja tidak relevan dalam kasus ini. ${ }^{5)}$

Jika di titik ini saja negara telah gagal maka sulit untuk mengurai kasus demi kasus yang terjadi, padahal awal mula diterbitkannya UndangUndang Nomor 11 Tahun 1980 tentang Tindak Pidana Suap justru untuk merespon suap dalam cabang sepak bola yang sangat nyata terjadi pada saat itu, banyaknya hasil pertandingan yang tak masuk akal ditambah lagi minimnya dokumentasi video membuat periode 70-80an menjadi panggung sandiwara sepak bola.

Skor diatur demi kepentingan bandar judi, masyarakat resah, kehormatan dan sportifitas pun tergadai. Langkah maju negara dengan menerbitkan Undang-Undang Nomor 11 Tahun 1980 tentang Tindak Pidana Suap sebenarnya bisa menjadi terobosan untuk menjerat semua tindak pidana suap di sektor swasta (non-government) namun karena kondisi politik rezim orba yang melindungi swasta kolega penguasa dan euforia reformasi yang menempatkan suap menjadi populer dalam konteks tipikor maka UU yang sebenarnya masih eksis dan berlaku ini menjadi terlupakan. Walau bisa saja karena strategi seperti memilih lawan di babak berikut misalnya, namun fakta menyatakan bahwa motif utama terkait pengaturan skor adalah uang. Sindikat judi bermodal besar berani membuat skenario terkait suatu hasil pertandingan karena mereka memiliki banyak uang untuk bermain di banyak titik.

Berdasarkan hal tersebut harus dipahami bahwa selama tak memenuhi unsur-unsur tertentu yang diatur secara pidana maka suatu pengaturan skor tak dapat dimasukkan kategori kejahatan/kriminal namun tetap saja mencederai fairplay. Karena ada juga pengaturan skor yang motifnya

5) Eko Noer Kristiyanto, "Tindak Pidana Pengaturan Skor", http://www.pikiranrakyat.com/kolom/2017/12/03/tindak-pidana-pengaturan-skor-415021, diakses tanggal 31 Maret 2018. 
bukan uang tetapi murni strategi untuk menghindari/memilih lawan dan sebagainya.

Suatu tindakan dapat dipidana jika termasuk dalam delik pidana, suatu delik haruslah memenuhi unsur-unsur tertentu. Dan penyuapan terkait pengaturan skor memenuhi syarat tersebut jika kita melihat ketentuan Pasal 2, Pasal 3, dan Pasal 5 Undang-Undang Nomor 11 Tahun 1980 tentang Tindak Pidana Suap yang secara garis besar menyatakan bahwa adalah termasuk tindak pidana kejahatan barangsiapa memberi atau menjanjikan sesuatu kepada seseorang dengan maksud untuk membujuk supaya orang itu berbuat sesuatu atau tidak berbuat sesuatu dalam tugasnya, yang berlawanan dengan kewenangan atau kewajibannya yang menyangkut kepentingan umum serta menerima sesuatu atau janji, sedangkan ia mengetahui atau patut dapat menduga bahwa pemberian sesuatu atau janji itu dimaksudkan supaya ia berbuat sesuatu atau tidak berbuat sesuatu dalam tugasnya, yang berlawanan dengan kewenangan atau kewajibannya yang menyangkut kepentingan umum.

Terlebih dalam penjelasan Pasal 2 Undang-Undang Nomor 11 Tahun 1980 tentang Tindak Pidana Suap disebutkan bahwa yang dimaksud dengan "kewenangan dan kewajibannya" termasuk kewenangan dan kewajiban yang ditentukan oleh kode etik profesi atau yang ditentukan oleh organisasi masing-masing-cetak tebal oleh penulis. Kode etik profesi ini tentunya mengikat para pemain yang masuk kategori berprofesi pemain sepakbola, dan mereka yang terlibat suap jelas-jelas melanggar pula ketentuan dan etik yang ditetapkan oleh organisasi-baca: federasi dari tingkat nasional hingga pusat (FIFA).

Dalam hal ini, aparat berwenang selalu beralasan ketiadaan hukum untuk menjerat para pelaku suap sepakbola, padahal pada kenyataannya Undang-Undang Nomor 11 Tahun 1980 tentang Tindak Pidana Suap masih eksis dan berlaku sebagai hukum positif di negeri ini. Mungkin saja karena selama ini tindak pidana suap seringkali dikaitkan dan mengacu kepada UU tindak pidana korupsi yang tentu saja unsur-unsur deliknya berbeda, 
sehingga terdapat "kecelakaan berpikir" bahwa suap dalam sepakbola tidak dapat dipidana karena tak memenuhi unsur "merugikan keuangan negara" sebagaimana diatur dalam UU Tipikor.

Undang-Undang Nomor 11 Tahun 1980 tentang Tindak Pidana Suap menjadi harapan untuk menjerat para pelaku yang terbukti terlibat dalam pengaturan skor sepakbola. Namun mengingat usia Undang-Undang Nomor 11 Tahun 1980 tentang Tindak Pidana Suap yang cukup tua-seperti sanksi belasan juta yang dirasa sangat ringan diera sekarang, sementara modus operandi match fixing terus berkembang maka terobosan-terobosan dan penemuan hukum/rechtsvinding utamanya yang dilakukan para hakim menjadi sangat penting, karena dapat dijadikan preseden dikemudian hari, terlebih Undang-Undang Nomor 48 Tahun 2009 tentang Kekuasaan Kehakiman menjamin hak dan kewajiban hakim untuk menemukan hukum dalam setiap putusannya.

Di sisi lain, dengan diberlakukannya Undang-Undang Nomor 3 Tahun 2005 tentang Sistem Keolahragaan Nasional tentunya akan menjadi landasan yuridis bagi setiap kegiatan keolahragaan di seluruh Indonesia. Undang-Undang Nomor 3 Tahun 2005 tentang Sistem Keolahragaan Nasional ini akan memberikan kepastian hukum bagi pemerintah pusat, pemerintah daerah dan masyarakat dalam kegiatan keolahragaan dalam mewujudkan masyarakat dan bangsa yang gemar, aktif, sehat dan bugar, serta berprestasi dalam olahraga.

\section{B. Perumusan Masalah}

Berdasarkan latar belakang yang diuraikan di atas, maka yang jadi pokok permasalahan adalah bagaimana kriminalisasi match fixing dalam pertandingan sepakbola di Indonesia berdasarkan Undang-Undang Nomor 11 tahun 1980 tentang Tindak Pidana Suap?

\section{Pembahasan}


Terkait dengan kriminalisasi match fixing dalam pertandingan sepakbola di Indonesia berdasarkan Undang-Undang Nomor 11 tahun 1980 tentang Tindak Pidana Suap. Hal yang perlu dimengerti bahwa kriminalisasi merupakan tindakan atau penetapan penguasa mengenai perbuatan-perbuatan tertentu yang oleh masyarakat atau golongan-golongan masyarakat dianggap sebagai perbuatan yang dapat di pidana menjadi perbuatan pidana atau membuat suatu perbuatan menjadi perbuatan kriminal dan karena itu dapat dipidana oleh pemerintah dengan cara kerja atas namanya. ${ }^{6)}$ Di sisi lain, Kriminalisasi dapat pula diartikan sebagai proses penetapan suatu perbuatan seseorang sebagai perbuatan yang dapat dipidana. Proses ini diakhiri dengan terbentuknya undang-undang di mana perbuatan itu diancam dengan suatu sanksi yang berupa pidana. ${ }^{7)}$

Kebijakan kriminalisasi merupakan menetapkan perbuatan yang semula bukan tindak pidana menjadi suatu tindak pidana dalam suatu peraturan perundang-undangan. Pada hakikatnya, kebijakan kriminalisasi merupakan bagian dari kebijakan kriminal dengan menggunakan sarana hukum pidana, dan oleh karena itu termasuk bagian dari kebijakan hukum pidana. ${ }^{8)}$

Berkaitan dengan penanggulangan kejahatan diperlukan berbagai sarana sebagai reaksi yang dapat diberikan kepada pelaku kejahatan, berupa sanksi pidana maupun non pidana, yang dapat diintegrasikan satu dengan yang lainnya dan apalagi sarana pidana dianggap relevan untuk menanggulangi kejahatan, berarti diperlukan konsepsi politik hukum pidana, yakni mengadakan pemilihan untuk mencapai hasil perundang-undangan pidana yang sesuai dengan keadaan dan situasi pada suatu waktu dan untuk masamasa yang akan datang. ${ }^{9)}$

Kebijakan hukum pidana berkaitan dengan masalah kriminalisasi yaitu perbuatan apa yang dijadikan tindak pidana dan penalisasi yaitu sanksi apa

\footnotetext{
6) Soerjono Soekanto, Kriminologi: Suatu Pengantar, Cetakan Pertama, (Jakarta: Ghalia Indonesia, 1981), 62.

7) Sudarto, Kapita Selekta Hukum Pidana, (Bandung: Alumni, 1986), 3.

8) Barda Nawawie Arief, Bunga Rampai Kebijakan Hukum Pidana, (Bandung: Citra Aditya Bakti, 2008), 2-3.

${ }^{9)}$ Sudarto, Hukum dan Hukum Pidana, (Bandung: Alumni, 1983), 109.
} 
yang sebaiknya dikenakan pada si pelaku tindak pidana. Kriminalisasi dan penaliasi menjadi masalah sentral yang untuk penanganannya diperlukan pendekatan yang berorientasi pada kebijakan (policy oriented approach). Kriminalisasi (criminalisation) mencakup lingkup perbuatan melawan hukum (actus reus), pertanggungjawaban pidana (mens rea) maupun sanksi yang dapat dijatuhkan baik berupa pidana (punishment) maupun tindakan (treatment). Kriminalisasi harus dilakukan secara hati-hati, jangan sampai menimbulkan kesan represif yang melanggar prinsip ultimum remedium (ultima ratio principle) dan menjadi bumerang dalam kehidupan sosial berupa kriminalisasi yang berlebihan (oever criminalisation), yang justru mengurangi wibawa hukum. Kriminalisasi dalam hukum pidana materiil akan diikuti pula oleh langkah-langkah pragmatis dalam hukum pidana formil untuk kepentingan penyidikan dan penuntutan. ${ }^{10)}$

Secara filosifi, pidana suap merupakan mala per se (tindakan yang jahat karena tindakan itu sendiri) atau mala in se (tindakan yang disebut jahat karena dilarang oleh tata hukum positif) dan bukan mala in prohibita. Konsep mala per se dilandasi oleh pemikiran natural wrongs yang menganggap bahwa kejahatan-kejahatan tentu merupakan kejahatan yang berkaitan dengan hati nurani dan dianggap tercela bukan karena peraturan perundang-undangan telah melarangnya, melainkan memang sudah dengan sendirinya salah.

Konsep mala in prohibitia bertitik tolak dari pemikiran bahwa perbuatan dianggap tercela atau salah karena perundang-undanag telah melarangnya, sehingga disebut juga sebagai regulatian offenses. Tindak pidana suap merupakan male per se karena penyuapan selalu mengisyaratkan adanya maksud untuk mempengaruhi agar disuap berbuat atau tidak berbuat sesuatu yang bertentangan dengan kewajibannya, atau juga karena yang disuap telah melakukan sesuatu atau tidak melakukan sesuatu yang bertentangan dengan kewajibannya. ${ }^{11)}$

${ }^{10)}$ Muladi, Kebijakan Kriminal terhadap Cybercrime, Majalah Media Hukum Vol. 1 No. 3 tanggal 22 Agustus 2003, 1-2.

${ }^{11)}$ Agus Budanto, Delik Suap Korporasi di Indonesia, Cetakan Pertama, (Bandung: Karya Putra Darwati, 2012), 5. 
Berdasarkan pengertian disebut di atas, maka delik suap dikatakan mala in probhita, baik delik tersebut masuk dalam pengertian merugikan keuangan negara dan Pasal 12 dalam Undang-Undang tindak pidana korupsi. Maupun, delik suap itu dilakukan oleh perusahaan swasta dan yang ditujukan oleh badan hukum atau perseorangan yang bukan Pegawai Negeri, yang tunduk pada ketentuan Undang-Undang Nomor Republik Indonesia Nomor 11 Tahun 1980 tentang Tindak Pidan Suap.

Kasus penyuapan yang melibatkan saksi di pengadilan tergolong tindak pidana berat, sebab ia tidak hanya berkaitan dengan tindak pidana suap sebagaimana diatur dalam peraturan perundang-undangan, tetapi juga berkaitan dengan asas peradilan yang jujur dan tindak pidana berupa gangguan terhadap proses memperoleh keadilan yang juga masuk kategori kejahatan melawan administrasi peradilan.

Tidak ditemukan parameter spesifik yang menjadi tolak ukur dari frasa "kepentingan umum", selain unsur kepentingan masyarakat/negara/bangsa. Dengan demikian, frasa "kepentingan umum" dapat dimaknai secara luas sepanjang di dalamnya termuat kepentingan masyarakat/negara/bangsa. Oleh karena itu, dengan mengacu pada unsur suap dalam UU Nomor 11 Tahun 1980 tentang Tindak Pidana Suap, maka dalam hal penerima suap adalah pihak dengan kewenangan yang dapat mempengaruhi kepentingan masyarakat/negara/bangsa, sehingga dapat dijerat dengan UU Nomor 11 Tahun 1980 tentang Tindak Pidana Suap.

Suap yang dilakukan pada sektor swasta merupakan bentuk implementasi dari perbuatan menyalahgunakan kewenangan dan perbuatan melawan hukum. Jadi, pemahaman korupsi di sektor swasta lebih dikaitkan pada perbuatan suap. Bahkan, perbuatan suap oleh dan di antara swasta juga sudah diatur dalam UU Nomor 11 Tahun 1980 tentang Tindak Pidana Suap, yang meletakkan unsur "kepentingan umum" sebagai dasar pemidanaan.

Dengan demikian, yang membedakan antara tindak pidana suap pada UU Nomor 11 Tahun 1980 tentang Tindak Pidana Suap dan pidana suap yang terakomodasi dalam Undang-Undang Nomor 21 Tahun 2002 tentang Tindak 
Pidana Korupsi adalah bahwa tindak pidana suap hanya berkaitan dengan perbuatan yang dinamakan private briber, serta tidak adanya persyaratan pada public official bribery, seperti hubungan antara kekuasaan dan jabatan sebagaimana rumusan yang ada dalam tindak pidana korupsi. Selain itu, kepentingan umum (public interest) merupakan syarat yang melekat pada delik inti dalam UU Nomor 11 Tahun 1980 tentang Tindak Pidana Suap, di mana rumusan unsur "kepentingan umum" tidak ditemukan dalam tindak pidana korupsi.

Pengaturan skor dengan melibatkan keuntungan berupa materi maupun immateriil erat kaitannya dengan UU Nomor 11 Tahun 1980 tentang Tindak Pidana Suap. Pasal 2 UU Nomor 11 Tahun 1980 tentang Tindak Pidana Suap menyatakan bahwa:

"Barangsiapa memberi atau menjanjikan sesuatu kepada seseorang dengan maksud untuk membujuk supaya orang itu berbuat sesuatu atau tidak berbuat sesuatu dalam tugasnya, yang berlawanan dengan kewenangan atau kewajibannya yang menyangkut kepentingan umum, dipidana karena memberi suap dengan pidana penjara selama-lamanya 5 (lima) tahun dan denda sebanyak-banyaknya Rp.15.000.000,- (lima belas juta rupiah)"

Dilanjutkan dengan Pasal 3 UU Nomor 11 Tahun 1980 tentang Tindak Pidana Suap yang menyatakan bahwa :

"Barangsiapa menerima sesuatu atau janji, sedangkan ia mengetahui atau patut dapat menduga bahwa pemberian sesuatu atau janji itu dimaksudkan supaya ia berbuat sesuatu atau tidak berbuat sesuatu dalam tugasnya, yang berlawanan dengan kewenangan atau kewajibannya yang menyangkut kepentingan umum, dipidana karena menerima suap dengan pidana penjara selama-lamanya 3 (tiga) tahun atau denda sebanyakbanyaknya Rp.15.000.000.- (lima belas juta rupiah)”.

Kedua pasal UU Nomor 11 Tahun 1980 tentang Tindak Pidana Suap di atas menurut penulis digunakan oleh penegak hukum Indonesia untuk menjerat para pelaku pengaturan skor jika memang ditemukan adanya indikasi suap menyuap di dalamnya. Karena dalam penjelasannya ditegaskan pada pasal 1 , kalimat "kewenangan dan kewajibannya" termasuk dengan yang melekat pada 
ketentuan kode etik dan profesi atau organisasinya masing-masing pelaku yang terlibat dalam tindak pidana ini.

Penulis dalam hal ini menggambarkan bahwa motif utama orang melakukan pengaturan skor (match fixing) adalah uang. Sindikat perjudian tentu bermodal besar untuk membuat skenario hasil pertandingan, dan hal ini jelas suatu tindakan kriminal. Meskipun secara jernih hal tersebut merupakan tindakan kriminal, maka terlebih dahulu harus membedakan bahwa selama tak memenuhi unsur-unsur tertentu maka suatu pengaturan skor tak dapat dimasukkan kategori kejahatan atau kriminal, namun semata mencederai fairplay. Karena ada juga pengaturan skor yang motifnya bukan uang, tetapi murni strategi untuk menghindari atau memilih lawan.

Kejelasan motif menjadi sangat penting dalam pengusutan pengaturan skor. Seringkali masyarakat pun mendahulukan asumsi daripada fakta. Misalnya kasus sepakbola antara PSS vs PSIS beberapa waktu lalu. Banyak masyarakat yang langsung berteriak bahwa polisi harus turun tangan. Padahal separah, sehina dan seterkutuk apapun sepakbola gajah di lapangan, selama tak memenuhi unsur delik pidana, maka urusan sanksi hanya sebatas ada di tangan Komisi Disiplin, Komisi Banding dan Komisi Etik PSSI.

Begitupun sebaliknya, ketika proses penyelidikan dan penyidikan menemukan fakta lain yang melibatkan pihak-pihak di luar football family seperti bandar judi, mafia dan lain-lain, maka federasi tak dapat menjangkaunya dan harus menggandeng aparat penegak hukum untuk memberantasnya. Kolaborasi seperti ini memang perlu komitmen dan itikad baik dari federasi, juga negara, seperti yang dilakukan Federasione Italiana Giuoco Calcio (FIGC) atau istilahnya PSSI-nya Italia ketika membongkar kasus calciopolli. Ketika terindikasi ada suap-menyuap dan pengaturan skor di serie A, maka FIGC menjalankan perannya, menjerat para pelaku di lingkaran football family dengan sanksi-sanksi seperti skorsing, hukuman degradasi., dsb. Tak cukup sampai di situ, ketika terbukti memenuhi unsur pidana yang merupakan yurisdiksi negara, maka federasi pun membuka akses yang seluasluasnya bagi aparat kepolisian dan kejaksaan untuk melaksanakan tugasnya. 
Sedangkan yang terjadi di negara Indonesia memang jauh dari itu. Contoh kecil saja, ketika skandal mafia wasit di era Djafar Umar terkuak, tampaknya cukup pemecatan, skorsing dan sanksi-sanksi administratif saja yang dilaksanakan. Padahal terkait suap menyuap sebenarnya diatur juga di KUHP. Atau jika ingin lebih spesifik, maka dapat kita lihat ketentuanketentuan dalam Undang-Undang Nomor 11 Tahun 1980 tentang Tindak Pidana Suap.

Suatu tindakan dapat dipidana jika termasuk ke dalam delik pidana, dan suatu delik haruslah memenuhi unsur-unsur tertentu. Jika satu unsur saja tak terpenuhi, maka tak dapat dikatakan sebagai suatu delik tertentu. Dapat kita temukan berbagai delik yang mirip namun berbeda unsur, rumusan serta sanksinya. Misalnya saja ada yang dinamakan pembunuhan, percobaan pembunuhan, pembunuhan berencana dan sebagainya. Itu berbeda-beda, dengan hukuman yang juga tidak sama.

Perlu diingat hukum pidana sangat kental dengan legisme serta positivistiknya. Sehingga ada prinsip yang bukan termasuk suatu tindak pidana terkecuali telah diatur sebagai suatu tindak pidana sebelumnya. Maka terobosan-terobosan dan penemuan hukum, utamanya yang dilakukan para hakim, menjadi sangat penting karena dapat dijadikan preseden di kemudian hari. Namun sayangnya kasus-kasus dan terobosan terkait pidana suap dalam bidang olahraga dapat dikatakan nihil di negeri ini. Padahal tanpa terobosan yang terlalu ekstrim pun sebenarnya instrumen hukum yang ada sudah cukup memadai jika saja aparat memang serius ingin memberantas suap dalam sepakbola.

Kasus pengaturan skor atau match fixing sudah lazim terjadi dalam dunia sepakbola, tak terkecuali di Indonesia. Berikut ini penulis menyajikan beberapa contoh match fixing, diantaranya adalah :

Pada Kejurnas PSSI 1961, Peristiwa memalukan menimpa PSM, dan orang lebih mengenalnya dengan "Peristiwa Surabaya". Dalam lanjutan kompetisi yang digelar di Stadion Tambaksari, 17 Juni 1961, secara mengejutkan Persebaya yang kala itu tergolong anak bawang, berhasil 
menahan tim kuat PSM dengan skor 3-3. Padahal, saat pertandingan berlangsung tim kebanggaan Jawa Timur tersebut sempat tertinggal 1-3 dari pasukan Ramang.

Hasil ini disikapi kritis oleh berbagai pihak, terutama kepada barisan penyerangan PSM yang selalu membuang peluang dengan percuma. Isu bahwa Ramang terkena suap langsung menyebar di mana-mana. Untuk menyikapi persoalan ini, pengurus PSM membentuk tim investigasi internal. Setelah beberapa minggu penyelidikan, tim investigasi itu berhasil membuktikan isu pengaturan skor di laga melawan Persebaya itu ternyata benar adanya.

Peristiwa Surabaya itu disindir oleh majalah ANEKA no. 13 pada edisi 1 Juni 1961. Sementara liputan tentang hasil investigasi internal PSM Makasar berikut laporan mengenai skorsing yang menimpa Ramang dan Noorsalam diberitakan majalah tersebut pada edisi September tahun yang sama. Dalam temuan tim investigasi internal PSM, pelaku pengaturan skor adalah Ramang dan Noorsalam.

Selanjutnya pada skandal Senayan 1962, juga menjadi aib kelam bagi Persib Bandung, PSM Makassar dan Persebaya Surabaya. Bagaimana tidak, enam pemain Persib, 3 pemain PSM dan satu pemain Persebaya yang kerap jadi pilihan utama pelatih Toni Pogacnik dinyatakan menerima suap dan terlibat dalam pengaturan skor.

Di awal Februari 1962, pencinta sepak bola Indonesia tengah berdebardebar menunggu hari Senin, 19 Februari 1962, momen di mana timnas Indonesia akan bertanding melawan tim All Star Vietnam Selatan di Stadion Ikada Jakarta.

Gosip pemain timnas yang ditangkap karena diduga mengatur skor sudah menyebar di mana-mana. Kebenaran isu itu hanya bisa dilihat dari starting eleven yang dipasang Toni Pogacnik saat menghadapi Vietnam. Dalam daftar starting line-up, tidak ada nama-nama tenar yang sebelumnya menjadi langganan timnas. Karena itulah para penonton yang hadir di Stadion Ikada saat itu mengerti bahwa rumor itu benar adanya. 
Pada tahun 1998, terjadi kasus suap dengan tema tawaran lolos ke babak 12 Besar Liga Indonesia. Djafar Umar yang menjabat Ketua Komisi Wasit PSSI pada saat itu beserta sepuluh wasit lainnya yang terbukti terlibat, menawarkan jasa mengatur hasil pertandingan pada klub peserta Liga Indonesia. Selang enam tahun kemudian, giliran Jimmy Napitupulu, wasit FIFA Indonesia, yang ditawari suap oleh pengurus Persebaya Surabaya agar "menyelamatkan" enam pemainnya yang rawan akumulasi kartu pada pertandingan melawan Persib Bandung.

Pada tahun 2000, salah satu kasus pengaturan pertandingan yang mencuat dan paling menyita perhatian adalah pengakuan Simon Legiman, manajer PSIS Semarang yang mengaku telah menyuap wasit Muchlis jelang laga Arema Malang kontra PSIS pada gelaran Liga Indonesia VI. Kasus ini menjadi menarik karena aktornya sendiri yang kemudian buka suara mengenai upaya penyuapan tersebut.

Menurut Simon, bukan dirinya yang ingin menyuap, tetapi Muchlis sendiri yang menawari. Pada perjanjian tersebut, Muchlis meminta Rp 3 juta jika seri dan Rp 5 juta apabila menang. ${ }^{12)}$ Simon jelas bersedia mengingat posisi tim berjuluk Mahesa Jenar kala itu sedang berada di jurang degradasi. Namun, saat pertandingan berlangsung, wasit justru banyak merugikan PSIS dan merekapun akhirnya kalah 2-3 dari tuan rumah. Simon yang sudah memberi uang muka Rp 1 juta pun berang dan 'bernyanyi' di hadapan wartawan seusai pertandingan.

Usut punya usut, ternyata Muchlis berniat untuk balas dendam lantaran dulu, saat PSIS juara, dirinya dijanjikan bonus Rp 10 juta. Namun, setelah PSIS berhasil menjadi juara Liga Indonesia V, uang yang diterimanya hanya Rp 750 ribu. Kasus ini pun berbuntut panjang. Simon kemudian dilarang berkiprah di sepak bola Indonesia seumur hidup dan wasit Muchlis pun dikenai sanksi berat. Pada akhir musim, PSIS akhirnya harus terdegradasi ke Divisi I, padahal musim sebelumnya mereka adalah juara liga.

${ }^{12)}$ Suara Merdeka, "Pengaturan Skor di Indonesia”, 29 Mei 2000. 
Pada tahun 2007, suap yang melibatkan official Penajam Medan Jaya (merger Penajam Putra Kalsel \& Medan Jaya) dengan oknum pengurus PSSI. Skandal dengan transaksi ratusan juta rupiah ini merupakan upaya pihak klub untuk membeli keputusan dari pengurus PSSI. Protes PSP Padang yang keberatan dengan keputusan PSSI yang mengijinkan Penajam Medan Jaya (PMJ) ikut kompetisi Divisi Satu 2007, karena pernah tersangkut kasus walk out saat melawan PS Tembilan, menjadi awal semua inisiatif jahat itu. Terancam gagal berkompetisi, PMJ kemudian mencoba melobi Komisi Disiplin yang ditugaskan Ketua Umum PSSI untuk menuntaskan masalah tersebut. Jadilah tawar menawar biaya keputusan untuk menyelamatkan PMJ. Meski sudah menyetor uang sebesar Rp100 juta namun pada akhirnya Komdis tetap mengeluarkan Surat Keputusan (SK) bertanggal 29 Mei 2007 yang isinya mendiskualifikasi, mendegradasi ke divisi dua, dan mendenda sebesar Rp50 juta pada Penajam Medan Jaya.

Pada tahun tahun 2010, Johan Ibo mencoba untuk menyuap dua pemain Pusamania Borneo FC (PBFC), Erick Weeks dan Oktovianus Maniani. Sebagai pemain kunci, tentu keduanya memiliki peranan penting dalam tim sehingga jika mereka bisa 'dipegang', maka jalannya pertandingan pun bisa diatur. Keduanya diharapkan agar bermain buruk sehingga mampu untuk membantu Persebaya 2010 memenangi pertandingan.

Pada tahun 2015, Biro Investigasi Praktik Korupsi Singapura (CPIB), berhasil meringkus seorang oknum asal Indonesia bernama Nasiruddin yang terlibat pengaturan skor (match fixing) pertandingan sepak bola di SEA Games 2015 lalu. Pengadilan Negeri Singapura lalu menjatuhkan hukuman 30 bulan penjara. Berdasarkan rekam jejaknya, tindakan pria berusia 52 tahun itu bukan yang pertama.

Nasiruddin tertangkap tangan CPIB terkait keterlibatannya dalam kasus suap laga pembuka Grup B cabang sepak bola SEA Games 2015 yang mempertemukan Timor Leste vs Malaysia, 30 Mei 2015. Untuk mempertanggungjawabkan perbuatannya, dan dipenjara selama 30 bulan atau 2,5 tahun di Singapura. 
Nasiruddin bersama 10 orang wasit Indonesia lainnya terbukti terlibat match fixing dalam ajang SEA Games 1997. Kasus tersebut juga menyeret nama Djafar Umar yang saat itu menjabat sebagai Ketua Komisi Wasit PSSI. Nasiruddin pernah dihukum larangan berkecimpung dalam sepak bola Indonesia selama 10 tahun. Ironisnya, 'Sang Mantan Wasit' kini terjerat kasus yang sama di negara tetangga.

Berbicara mengenai penerapan sanksi, terdapat dua kelompok sports law yang memiliki cara pandang berbeda dalam melihat bagaimana hukum diberlakukan dalam bidang olahraga, yang terdiri dari Domestic Sports Law dan Global Sports Law dan National Sports Law dan International Sports Law. Kelompok tersebut di satu sisi memperbolehkan dan pada sisi lainnya menolak hukum negara melalui (misalnya hukum pidana) masuk ke dalam sepak bola. Mereka yang menolak hukum negara masuk, menunjukkan keinginan dari organisasi olahraga untuk menyelesaikan sendiri sengketa yang timbul pada cabang olahraga mereka dan mengklaim bahwa melalui mekanisme ini mereka telah mengembangkan sebuah cabang baru dari hukum, yang kemudian disebut sebagai lex sportiva. Lex sportiva merupakan sebuah bentuk lex specialis yang dapat diterapkan dalam dunia olahraga internasional, karena ia bersumber secara langsung dari konstitusi yang dibentuk oleh federasi olahraga untuk menjalankan olahraga yang bersangkutan. Mudahnya, kalau ingin ditafsirkan secara sederhana, lex sportiva adalah peraturan yang dibuat oleh induk organisasi olahraga, yakni semacam AD/ART organisasi atau statuta organisasi dimana setiap anggota harus tunduk terhadap AD/ART atau statutanya.

Selain cara pandang berbeda dalam melihat bagaimana hukum diberlakukan dalam bidang olahraga, ada alasan lain yang keberatan terhadap penggunaan sanksi pidana dari hukum suatu negara. Alasan itu ialah negara bisa dikenakan sanksi oleh FIFA, apabila mengintervensi sepak bola melalui cara apapun. Adanya sanksi dari FIFA bisa berakibat sepak bola tidak pernah ada dalam negara tersebut. Tentunya bagi pecinta sepak bola, ini adalah kiamat. Lalu, bagaimana sikap FIFA ? Ternyata menghadapi permasalahan 
pengaturan skor ini, FIFA mendukung segala upaya untuk memerangi pengaturan skor, termasuk dengan hukum pidana. Bahkan, FIFA pun telah bekerja sama dengan Interpol dan berbagai elemen yang ada, termasuk negara untuk mengatasi pengaturan skor ini. FIFA beralasan bahwa kelompok kejahatan internasional yang terorganisir (International organized crime groups) terlibat dalam pengaturan pertandingan di sepak bola. Pengaturan pertandingan di sepak bola merupakan tantangan global yang membutuhkan respon yang terkoordinasi dari berbagai pemangku kepentingan di tingkat nasional, regional dan internasional.

Selain itu, salah satu hal yang harus dicermati adalah sanksi disiplin FIFA hanya dapat menjatuhkan hukuman kepada para family football, di luar itu FIFA tidak bisa menjangkaunya dan beberapa negara di dunia pun ternyata telah memiliki ketentuan hukum pidana mengenai pengaturan skor ini dan negara-negara tersebut tidak dijatuhi hukuman oleh FIFA. Dengan demikian, khusus permasalahanmatch fixing initidak melanggar asas otonomi dalam olahraga, seperti yang kita pahami sebagai lex sportiva. Dengan begitu, kriminalisasi terhadap pengaturan skor seperti yang sudah tertuang di RKUHP, sebagai bagian dari tindak pidana korupsi tidak menjadi soal. Masalahnya sekarang adalah bagaimana merespon kerja sama dari FIFA terhadap pengaturan skor saat ini. Tentu, mekanisme yang bisa digunakan oleh Indonesia bisa melalui hukum pidana. Pengaturan skor dalam sepak bola bisa dipidana, dan tetapi bagaimana menanganinya, bukankah pengaturan skor belum ada ketentuan pidananya di Indonesia dan juga yurisprudensi untuk masalah ini pun belum pernah ada.

Hal yang perlu dipahami adalah UU Tipikor tidak tepat menjerat pelaku dan penerima suap dari pihak swasta, khususnya di dunia olahraga. UU Tipikor itu bersifat lex specialis, pengertian suap di sana adalah yang merugikan keuangan negara dan berlaku untuk kasus korupsi yang ada hubungannya dengan penyelenggara negara. Guna menjerat pelaku dan penerima suap dari pihak swasta, penulis tetap menyarankan untuk menggunakan Undang-Undang Nomor 11 Tahun 1980 tentang tindak pidana suap yang kelahirannya dipicu 
fenomena perjudian dan match-fixing di sepakbola pada masa lalu. Artinya bahwa ini bukan undang-undang yang digugurkan setelah lahirnya UU Tipikor. Undang-undang ini bisa menjerat orang-orang yang terlibat suap, walau dia bukan elemen dari pemerintah atau penyelenggara negara. UU ini masih eksis dan bisa menjerat pihak swasta.

Beberapa kasus pengaturan skor di ranah olahraga Indonesia tidak berlanjut ke hukuman pidana, di mana gugatan pidana ini dinilai akan lebih efektif memerangi pengaturan skor dan judi dalam olahraga, selain sanksi yang dijatuhkan induk olahraga.

Pada skala internasional, sebagai contoh Federasi Sepak bola Italia menyatakan Juventus bersalah terlibat pengaturan skor dan didegradasi ke divisi dua kompetisi alias Serie B. Gelar juara Juventus di Serie A pada musim 2004-2005 juga dicopot. Adapun AC Milan mendapat pengurangan sejumlah poin di kompetisi Serie A. Sanksi tak berhenti di situ. Ada tuntutan jaksa kepada beberapa orang yang akhirnya dipenjara. Jadi seharusnya ketika federasi sudah memberi sanksi, maka berlanjut ke hukum negara.

Berbicara mengenai sanksi pidana (menjerat pelaku tindak pidana) secara pidana adalah bicara unsur-unsur untuk terpenuhinya suatu delik, maka harus pintar-pintarnya para penyelidik dan penyidiklah menjadikan temuantemuan sebagai unsur delik, sebagai contoh suap dalam sepakbola yang melibatkan wasit, pemain atau pihak di luar football family dapat dijerat pidana. Pasal 2 hingga Pasal 5 Undang-Undang Nomor 11 Tahun 1980 Tentang Tindak Pidana Suap.

Pasal 2

Barangsiapa memberi atau menjanjikan sesuatu kepada seseorang dengan maksud untuk membujuk supaya orang itu berbuat sesuatu atau tidak berbuat sesuatu dalam tugasnya, yang berlawanan dengan kewenangan atau kewajibannya yang menyangkut kepentingan umum, dipidana karena memberi suap dengan pidana penjara selama-lamanya 5 (lima) tahun dan denda sebanyak-banyaknya Rp.15.000.000,- (lima belas juta rupiah).

Pasal 3 
Barangsiapa menerima sesuatu atau janji, sedangkan ia mengetahui atau patut dapat menduga bahwa pemberian sesuatu atau janji itu dimaksudkan supaya ia berbuat sesuatu atau tidak berbuat sesuatu dalam tugasnya, yang berlawanan dengan kewenangan atau kewajibannya yang menyangkut kepentingan umum, dipidana karena menerima suap dengan pidana penjara selama-lamanya 3 (tiga) tahun atau denda sebanyak-banyaknya Rp.15.000.000.- (lima belas juta rupiah).

Pasal 4

Apabila tindak pidana tersebut dalam Pasal 2 dan Pasal 3 dilakukan di luar wilayah Republik Indonesia, maka ketentuan dalam undang-undang ini berlaku juga terhadapnya.

Pasal 5

Tindak pidana dalam undang-undang ini merupakan kejahatan.

Berdasarkan ketentuan di atas sudah cukup menjerat pemberi suap, penerima suap, tak peduli di manapun locus (lokasi) penyuapan, apalagi jika terkait perjudian yang nyata-nyata diatur pula oleh KUHP. Maka lengkaplah sudah suap-pengaturan skor sebagai sesuatu yang mengganggu ketertiban serta kepentingan umum dan hukum pidana harus ditegakkan guna menjaga stabilitas masyarakat.

Terlebih dalam penjelasan Pasal 2A Undang-Undang Nomor 11 Tahun 1980 tentang Tindak Pidana Suap disebutkan bahwa yang dimaksud dengan "kewenangan dan kewajibannya", termasuk kewenangan dan kewajiban yang ditentukan oleh kode etik profesi atau yang ditentukan oleh organisasi masingmasing. Kode etik profesi ini tentunya mengikat para pemain yang masuk kategori berprofesi pemain sepakbola, dan mereka yang terlibat suap jelas-jelas melanggar pula ketentuan dan etik yang ditetapkan oleh organisasi atau federasi dari tingkat nasional hingga FIFA).

Berkenaan dengan hal tersebut tentunya miris rasanya jika untuk menjerat para pelaku suap dan pengaturan skor saja masih ada yang beralasan belum ada aturannya (lalu melepas si pelaku yang jelas-jelas tertangkap tangan). Alasan lain yang seakan-akan benar adalah perlu menunggu aturan yang memasukkan ketentuan suap olahraga dalam rancangan KUHP yang baru ataupun memasukkan ketentuan ini dalam rancangan Sistem Keolahragaan 
Nasional yang baru. Sekali lagi kuncinya adalah niat dan komitmen, karena memang pemberantasan suap-pengaturan skor bukanlah suatu hal yang mudah. Jangankan di Indonesia, di negara yang sepakbolanya maju serta terintegrasi sistem pun, match fixing tetap menjadi momok yang selalu mengintai setiap musim kompetisi.

Khusus di Indonesia kasus match fixing seperti yang dijelaskan di Bab III, seharusnya bisa menjadi momentum baik, karena jarang-jarang ada pelaku suap (sekelas Johan Ibo) yang seceroboh ini lalu kemudian dilepaskan begitu saja, mengingat ada undang-undang yang bisa menjeratnya terkait dengan sanksi hukum yang bisa diterapkan.

Jika kita melihat ketentuan Pasal 2, Pasal 3, dan Pasal 5 UndangUndang Nomor 11 Tahun 1980 tentang Tindak Pidana Suap di atas, yang secara garis besar menyatakan bahwa adalah termasuk tindak pidana kejahatan barangsiapa memberi atau menjanjikan sesuatu kepada seseorang dengan maksud untuk membujuk supaya orang itu berbuat sesuatu atau tidak berbuat sesuatu dalam tugasnya, yang berlawanan dengan kewenangan atau kewajibannya yang menyangkut kepentingan umum serta menerima sesuatu atau janji, sedangkan ia mengetahui atau patut dapat menduga bahwa pemberian sesuatu atau janji itu dimaksudkan supaya ia berbuat sesuatu atau tidak berbuat sesuatu dalam tugasnya, yang berlawanan dengan kewenangan atau kewajibannya yang menyangkut kepentingan umum.

Terlebih dalam penjelasan Pasal 2 Undang-Undang Nomor 11 Tahun 1980 tentang Tindak Pidana Suap disebutkan bahwa yang dimaksud dengan "kewenangan dan kewajibannya" termasuk kewenangan dan kewajiban yang ditentukan oleh kode etik profesi atau yang ditentukan oleh organisasi masing-masing-cetak tebal oleh penulis. Kode etik profesi ini tentunya mengikat para pemain yang masuk kategori berprofesi pemain sepakbola, dan mereka yang terlibat suap jelas-jelas melanggar pula ketentuan dan etik yang ditetapkan oleh organisasi atau federasi dari tingkat nasional hingga pusat (FIFA). 
Berkenaan dengan hal tersebut, penulis sependapat dengan Bapak Andi Hamzah bahwa pada dasarnya Undang-Undang Nomor 11 Tahun 1980 tentang Tindak Pidana Suap diambil dari KUHP Belanda, di mana di Belanda ada pejabat negara, non pejabat negara ada, di Indonesia hanya ada pejabat negara, sedangkan non pejabat negara tidak diadopsi di dalamnya. Pada persepsi ini, suap di sektor swasta tidak dapat dikatakan sebagai suatu tindakan korupsi karena tidak masuk sebagai kategori korupsi berdasarkan UU Tipikor. Hal tersebut bukan berarti tidak memiliki dampak sama sekali dalam penegakan peraturan tersebut. Justru tidak diaturnya ketentuan suap di sektor swasta pada UU Tipikor memiliki keterkaitan dengan aktor yang dapat melakukan pemberantasan dan penegakan ketentuan tersebut. Singkatnya, seringkali penegakan hukum korupsi dikaitkan hanya dengan Komisi Pemberantasan Korupsi (KPK). KPK hanya memiliki kewenangan dalam undang-undang korupsi, di luar itu bukan wewenang KPK. Jadi dalam Undang-Undang Nomor 11 Tahun 1980 tentang Tindak Pidana Suap, penyidikan bisa dilakukan jaksa atau pihak kepolisian.

Menurut Penulis bahwa Undang-Undang Nomor 11 Tahun 1980 tentang Tindak Pidana Suap menjadi harapan untuk menjerat para pelaku yang terbukti terlibat dalam pengaturan skor sepakbola. Namun mengingat usia Undang-Undang Nomor 11 Tahun 1980 tentang Tindak Pidana Suap yang cukup tua-seperti sanksi belasan juta yang dirasa sangat ringan di era sekarang, sementara modus operandi match fixing terus berkembang, maka terobosanterobosan dan penemuan hukum atau rechtsvinding utamanya yang dilakukan para hakim menjadi sangat penting, karena dapat dijadikan preseden di kemudian hari, terlebih Undang-Undang Nomor 48 Tahun 2009 tentang Kekuasaan Kehakiman menjamin hak dan kewajiban hakim untuk menemukan hukum dalam setiap putusannya.

\section{Penutup}

\section{A. Kesimpulan}


Berdasarkan pembahasan yang telah diuraikan pada bab-bab sebelumnya, maka dapat disimpulkan bahwa kriminalisasi match fixing dalam pertandingan sepakbola di Indonesia berdasarkan Undang-Undang Nomor 11 Tahun 1980 tentang Tindak Pidana Suap diancam dengan suatu sanksi yang berupa pidana meskipun suap di sektor swasta tidak dapat dikatakan sebagai suatu tindakan korupsi karena tidak masuk sebagai kategori korupsi berdasarkan UU Tipikor. Ini artinya bahwa hal tersebut bukan berarti tidak memiliki dampak sama sekali dalam penegakan peraturan tersebut. Justru tidak diaturnya ketentuan suap di sektor swasta pada UU Tipikor memiliki keterkaitan dengan aktor yang dapat melakukan pemberantasan dan penegakan ketentuan tersebut. Mengingat seringkali penegakan hukum korupsi dikaitkan hanya dengan KPK. KPK hanya memiliki kewenangan dalam undang-undang korupsi, di luar itu bukan wewenang KPK. Jadi dalam Undang-Undang Nomor 11 Tahun 1980 tentang Tindak Pidana Suap, penyidikan bisa dilakukan oleh jaksa atau pihak kepolisian.

\section{B. Saran}

Berdasarkan kesimpulan tersebut, penulis menyarankan beberapa hal sebagai berikut:

1. Suap (maupun korupsi secara umum) di sektor swasta telah membawa begitu banyak dampak buruk terhadap sektor bisnis tak terkecuali dalam pertandingan sepak bola. Oleh karena itu, perlu adanya penegakan hukum untuk dapat memberikan penghukuman terhadap para pelaku suap di sektor swasta. Pemerintah melakukan penegakan hukum terhadap pelaku suap di sektor swasta secara konkret agar seluruh masyarakat Indonesia menyadari bahwa perbuatan tersebut merupakan perbuatan tercela dan tidak dapat dipandang sebagai suatu hal yang biasa.

2. Guna menjerat pelaku dan penerima suap dari pihak swasta, khususnya dalam pertandingan sepak bola, penulis tetap menyarankan untuk 
menggunakan Undang-Undang Nomor 11 Tahun 1980 tentang Tindak Pidana Suap yang kelahirannya dipicu fenomena perjudian dan matchfixing di sepakbola pada masa lalu. Artinya bahwa ini bukan undangundang yang digugurkan setelah lahirnya UU Tipikor. Undang-undang ini bisa menjerat orang-orang yang terlibat suap, walau mereka bukan elemen dari pemerintah atau penyelenggara negara. Undang-Undang Nomor 11 Tahun 1980 tentang Tindak Pidana Suap ini masih eksis dan bisa menjerat pihak swasta. 


\section{Daftar Pustaka}

\section{Buku}

Arief. Barda Nawawie. Bunga Rampai Kebijakan Hukum Pidana. Bandung: Citra Aditya Bakti, 2008.

Budanto. Agus. Delik Suap Korporasi di Indonesia. Cetakan Pertama. Bandung: Karya Putra Darwati, 2012.

Muladi. Kebijakan Kriminal terhadap Cybercrime. Majalah Media Hukum Vol. 1 No. 3 tanggal 22 Agustus 2003, 1-2.

Soekanto. Soerjono. Kriminologi: Suatu Pengantar. Cetakan Pertama. Jakarta: Ghalia Indonesia, 1981.

Sudarto. Hukum dan Hukum Pidana. Bandung: Alumni, 1983.

Sudarto. Kapita Selekta Hukum Pidana. Bandung: Alumni, 1986.

\section{Peraturan Perundang-undangan}

Indonesia. Undang-Undang Nomor 11 Tahun 1980 tentang Tindak Pidana Suap. (Lembaran Negara Republik Indonesia Tahun 1980 Nomor 58, Tambahan Lembaran Negara Nomor 3178).

. Undang-Undang Nomor 3 Tahun 2005 tentang Sistem Keolahragaan Nasional, (Lembaran Negara Republik Indonesia Tahun 2005 Nomor 89, Tambahan Lembaran Negara Republik Indonesia Tahun 2005 Nomor 4535).

\section{Koran}

Suara Merdeka, "Pengaturan Skor di Indonesia", 29 Mei 2000.

\section{Internet}

Ali. "FIFA: Sepakbola Telah Disusupi Kejahatan Terorganisir". http://www.hukumonline.com/berita/baca/lt5270ce5840661/fifa-sepakbola-telah-disusupi-kejahatan-terorganisir, diakses tanggal 16 Februari 2018. 
Ananda. Luthfy Avian. "Match Fixing dalam Sepakbola Indonesia Ditinjau dari Perspektif Hukum Pidana". https://www.kompasiana.com/luthfyavian/match-fixing-dalamsepakbola-indonesia-ditinjau-dari-perspektif-hukumpidana_5693d48e119773750970f220, diakses tanggal 18 Januari 2018.

Bozkurt, Emine. "Match Fixing and Fraud in Sport: Putting the Pieces Together".

http://www.europarl.europa.eu/document/activities/cont/201209/ 20120925ATT52303/20120925ATT52303EN.pdf, diakses tanggal 16 Februari 2018.

Kristiyanto. Eko Noer. "Tindak Pidana Pengaturan Skor", http://www.pikiran-rakyat.com/kolom/2017/12/03/tindak-pidanapengaturan-skor-415021. diakses tanggal 31 Maret 2018. 